\title{
ANALISIS WACANA TEKSTUAL DAN KONTEKSTUAL DALAM NASKAH DRAMA SENJA DENGAN DUA KELELAWAR KARYA KIRDJOMULYO DAN RELEVANSINYA SEBAGAI BAHAN AJAR DI SEKOLAH MENENGAH ATAS
}

\author{
Nina Nuryani ${ }^{1}$, Budhi Setiawan ${ }^{2}$, Kundharu Saddhono ${ }^{3}$ \\ Universitas Sebelas Maret \\ Email: nuryani_nina123@student.uns.ac.id ${ }^{1}$, buset.74@gmail.com², \\ kundharu.uns@gmail.com ${ }^{3}$
}

\begin{abstract}
Abstrak: Tujuan penelitian ini adalah untuk mendeskripsikan (1) bentuk analisis tekstual dalam naskah drama Senja dengan Dua Kelelawar karya Kirdjomulyo; (2) bentuk analisis kontekstualdalam naskah drama Senja dengan Dua Kelelawar karya Kirdjomulyo; dan (3) relevansi hasil penelitian ini sebagai bahan ajar pembelajaran bahasa Indonesia di Sekolah Menengah Atas. Penelitian ini termasuk penelitian kualitatif dengan sumber data utama adalah naskah drama Senja dengan Dua Kelelawar karya Kirdjomulyo. Uji validitas data yang digunakan ialah triangulasi teori. Teknik sampling penelitian ini menggunakan purposive sampling. Teknik analisis data yang digunakan ialah teknik analisis interaktif yang meliputi empat tahapan, yaitu: (1) pengumpulan data, (2) reduksi data, (3) penyajian data, dan (4) penarikan kesimpulan. Hasil penelitian ini menunjukkan bahwa dalam naskah drama Senja dengan Dua Kelelawar karya Kirdjomulyo menggunakan analisis aspek gramatikal dan leksikal untuk menganalisis secara tekstual. Pengguanaan analisis dari aspek gramatikal dan leksikal yang tepat mampu membentuk sebuah wacana yang memiliki kepaduan bentuk. Kepaduan bentuk wacana naskah drama tersebut didukung oleh aspek gramatikal, yaitu pengacuan, penyulihan, pelesapan, dan perangkaian. Dalam aspek gramatikal, didominasi oleh pengacuan. Pengacuan persona yang sering digunakan adalah pengacuan persona I tunggal, baik bentuk bebas aku, saya, bentuk lekat kiri ku-, dan bentuk lekat kanan -ku. Keserasian makna didukung pula oleh aspek leksikal, yaitu repetisi, sinonimi, antonimi, kolokasi, hiponimi, dan ekuivalensi.
\end{abstract}

Kata kunci: wacana, tekstual, aspek gramatikal, aspek leksikal, kontekstual, bahan ajar.

\section{TEXTUAL AND CONTEXTUAL ANALYSIS IN SENJA DENGAN DUA KELELAWAR PLAY SCRIPT BY KIRDJOMULYO AND IT'S RELEVANCE AS TEACHING MATERIAL IN SENIOR HIGH SCHOOL}

\begin{abstract}
The purpose of this study is to describe (1) the form of textual analysis in the drama script Senja dengan Dua Kelelawar by Kirdjomulyo; (2) the form of contextual analysis in the drama script Senja dengan Dua Kelelawar by Kirdjomulyo; and (3) the relevance of the results of this study as teaching materials for Indonesian language learning in senior high schools. This research is a qualitative research with the main data source as the drama script Senja dengan Dua Kelelawar by Kirdjomulyo. Data validity test used is theory triangulation. The sampling technique of this study used purposive sampling. Data analysis technique used is an interactive analysis technique that includes four stages, namely: (1) data collection, (2) data reduction, (3) data presentation, and (4) drawing conclusions. The results of this study indicate that in the drama script Senja dengan Dua Kelelawar by Kirdjomulyo uses grammatical and lexical aspects to analyze textually. The use of analysis of grammatical and lexical aspects is precisely able to form a discourse that has cohesive forms. The unified form of drama script discourse is supported by
\end{abstract}

BASASTRA Jurnal Bahasa, Sastra, dan Pengajarannya

Volume 8 Nomor 2, Oktober 2020, P-ISSN 2302-6405, E-ISSN 2714-9765 
grammatical aspects, namely reference, restoration, absorption, and sequencing. In grammatical aspects, it is dominated by reference. Persona referencing that is often used is single persona referencing, both my free form, mine, my left sticky form, and my right sticky form. Harmony of meaning is also supported by lexical aspects, namely repetition, synonymy, antonymy, collocation, hyponymy, and equivalence.

Keywords: discourse, textual, grammatical aspects, lexical aspects, contextual, teaching materials.

\section{PENDAHULUAN}

Komunikasi

merupakan

kegiatan atau hal yang akan terus dilakukan oleh manusia. Diperlukan sarana untuk pengungkapan ide, gagasan, isi, maksud, dan sebagainya, saat atau selama terjadinya proses komunikasi. Sarana paling utama untuk mengungkapkan keseluruhan hal dalam komunikasi tersebut adalah bahasa. Bahasa merupakan alat komunikasi yang digunakan untuk menganalisis pengalaman manusia secara berbeda di dalam lingkungan masyarakat, dalam satuan-satuan yang mengandung isi semantis dan pengungkapan bunyi, yaitu fonem (Setiawan, 2012: 15).

Lebih lanjut dijelaskan oleh Wijana dan Rohmadi (2008: 9) bahwa kemampuan manusia mengomunikasikan segala hal hanya dapat dilakukan dengan bahasa. Secara menyeluruh elemen dalam bahasa terdiri dari dua macam, yaitu elemen bentuk dan elemen makna, atau dengan kata lain disebut bentuk dan makna. Bahasa yang dilakukan oleh seseorang sangat dipengaruhi oleh bentuk dan makna itu sendiri.

Dilihat dari aspek penggunaannya, menurut Setiawan (2012: 15) alat komunikasi yang digunakan manusia dapat dibedakan atas media yang berupa bahasa (verbal) dan nonbahasa (nonverbal). Umumnya komunikasi dilakukan secara lisan atau verbal yang dapat dimengerti oleh kedua belah pihak tersebut. Terkait dengan hal tersebut, sarana komunikasi verbal dapat dibedakan menjadi dua, yaitu: (1) sarana komunikasi berupa behasa lisan dan (2) sarana komunikasi berupa bahasa tulis. Hal tersebut disampaikan juga dalam pendapat Sumarlam, dkk (2003:1) bahwa wacana atau tuturan dibedakan menjadi dua, yaitu wacana lisan dan wacana tulis.

Wacana lisan adalah bentuk wacana yang disampaikan secara lisan. Maksud dari lisandi atas adalah tanpa melalui media perantara apapun saat menyampaikannya. Wacana lisan yang dimaksud di sini misalnya saja seperti pidato, siaran berita, khotbah, yang disampaikan secara lisan. Sedangkan untuk wacana tulis merupakan wacana yang disampaikan melalui tulisan, misalnya karya-karya sastra (novel, cerpen, puisi,naskah drama) dan koran majalah. Metode yang digunakan dalam pengkajian wacana lisan dan wacana tulis tersebut menggunakan metode yang berbeda-beda. 
Wacana digunakan sebagai dasar dalam memahami sebuah teks dan sangat diperlukan oleh masyarakat bahasa agar dapat menyampaikan informasi dalam bentuk wacana secara utuh. Menurut Djajasudarma (1994: 3), wacana adalah satuan linguistik yang terlengkap dan tertinggi dalam hierarki gramatikal. Wacana memuat kesatuan makna secara utuh, dan di dalamnya juga mengandung semua unsur kebahasaan sehingga pantas jika wacana merupakan satuan bahasa terlengkap dan tertinggi.

Studi mengenai wacana sudah sering dilakukan. Salah satunya, yaitu mengenai penelitian tentang analisis pada wacana. Analisis wacana menurut Stubbs (dalam Wijana \& Rohmadi, 2011: 70) merujuk pada kajian terhadap satuan-satuan kebahasaan yang lebih luas, seperti halnya pertukaran percakapan dalam komunikasi maupun teks tulis. Pada dasarnya penelitian tentang analisis wacana membahas dan mendefinisikan pesan maupun makna yang dimaksud antara pesapa dan penyapa (Wijana \& Rohmadi, 2011:72).

Dari pengertian tersebut sudah jelas-jelas terlihat bahwa kajian mengenai analisis wacana sangat luas sehingga studi mengenai analsis wacana sangat menarik untuk diteliti lebih lanjut. Penelitian analisis tekstual kontekstual ini diharapkan dapat mengkaji lebih dalam sebuah wacana sehingga sebuah wacana dapat dipahami secara menyeluruh. Peneliti tertarik untuk melakukan penelitian mengenai analisis wacana pada sebuah teks sastra. Hal ini dikarenakan sastra memiliki kajian yang unik dengan makna-makna yang tersirat di dalamnya.

Sastra merupakanbentuk pengungkapan kehidupan nyata masyarakat secara imajiner dalam bentuk cerita fiksi (Priyatni, 2010: 12). Menurut Sapardi (dalam Priyatni, 2010: 12) sastra merupakan suatu lembaga sosial yang menggunakan bahasa sebagai media atau alat yang membantu terbentuknya suatu karya sastra, bahasa itu sendiri merupakan ciptaan sosial. Sebuah karya sastra umumnya berisi suatu pemikiran, gagasan atau ide, kisah-kisah hidup serta amanat atau pesan yang disampaikan terhadap para pembacanya. Untuk mengerti mengenai hal tersebut penikmat karya sastra harus bisa mengapresiasikan sebuah karya sastra. Dalam membaca karya sastra seseorang dituntut untuk aktif dan kreatif agar mampu mengerti dan menentukan keanekaragaman makna yang ada dalam karya sastra tersebut.

Salah satu jenis karya sastra ialah drama. Karya sastra drama adalah gambaran atau cerita kehidupan manusia yang dihadirkan atau ditampilkan dalam bentuk pementasan. Menurut Waluyo (2003: 2) drama merupakan gambaran tentang kehidupan manusia, baik dalam suka maupun duka, pahit atau manis, serta hitam-putih kehidupan manusia. Dalam membicarakan istilah drama kita akan dihadapkan pada dua kemungkinan, yaitu drama naskah dan 
drama pentas. Keduanya bersumber pada drama naskah. Naskah dalam sebuah drama di situ berisi cerita yang nantinya akan disajikan kepada para penikmat drama. Terkait dengan hal ini tentunya sebelum sebuah naskah drama tersebut dipentaskan para pemain (khususnya) harus dapat memahami isi dari drama tersebut. Apabila dilihat lebih jauh sebuah naskah drama dapat dijadikan bahan studi sastra.

\section{METODE}

Penelitian ini berlangsung selama lima bulan, yakni bulan Mei sampai dengan bulan September 2019. Metode penelitian yang digunakan adalah kualitatif desktriptif dengan pendekatan analisis dokumen (content analysis) pada naskah drama Senja dengan Dua Kelelawar Karya Kirdjomulyo. Penelitian kualitatif bermaksud untuk memahami fenomena tentang apa yang dialami oleh subjek penelitian misalnya perilaku, persepsi, motivasi, tindakan, dll. Secara holistik dan dengan cara deskripsi dalam bentuk kata-kata dan bahasa dalam suatu konteks khusus yang alamiah dan dengan memanfaatkan berbagai metode ilmiah (Moeloeng, 2004:6). Data dan sumber data yang digunakan adalah teks naskah drama Senja dengan Dua Kelelawar Karya Kirdjomulyo dan teks (transkrip wawancara) kepada dua guru mata pelajaran bahasa Indonesia di SMA MTA Surakarta. Pemilihan subjek penelitian dilakukan dengan purposive sampling. Menurut Sangidu
(2004:3) purposive sampling adalah teknik pengambilan sampel berdasarkan pertimbanganpertimbangan tertentu sesuai dengan objek formal penelitian yang dilakukan. Teknik pengumpulan data yang digunakan dalam penelitian ini adalah 1) Teknik studi pustaka digunakan untuk mencari buku-buku atau teori-teori mengenai wacana, analisis tekstual, analisis kontekstual ataupun literatur lain. Teori yang didapat dari literatur dijadikan pijakan untuk menganalisis data yang telah dikumpulkan, 2) Teknik dokumentasi digunakan untuk mengumpulkan datadata penelitian pada naskah drama Senja dengan Dua Kelelawar sebagai bahan ajar di Sekolah Menengah Atas, 3) Teknik catat digunakan untuk mencatat data-data yang ada dalam naskah drama Senja dengan Dua Kelelawar, 4) Teknik wawancara digunakan untuk memperkuat hasil penelitian sebagai bahan ajar Bahasa Indonesia di SMA. Uji validitas data 'yang digunakan adalah triangulasi teori, triangulasi teori ini dipilih karena peneliti menggunakan perspektif lebih dari satu teori dalam membahas permasalahan yang dikaji. Dari beberapa perspektif teori tersebut akan diperoleh pandangan yang lebih lengkap, tidak hanya sepihak, sehingga bisa dianalisis dan ditarik simpulan yang lebih utuh dan menyeluruh.

\section{HASIL DAN PEMBAHASAN}

Drama Senja dengan Dua Kelelawar merupakan sebuah drama 
yang menceritakan tentang kisah kehidupan di sebuah lingkungan stasiun yang menjadi latar utama dalam drama ini. Berawal dari cerita masa remaja Ismiyatii dengan Suwarto yang setiap hari berangkat sekolah bersama dan dalam satu kereta yang sama, muncullah benih-benih cinta di hati Ismiyati namun tidak dengan hati Suwarto. Keduanya sudah seperti saudara yang saling menyayangi, Suwarto menganggap Ismiyati sebagai adiknya karena Marsudi bapak Ismiyati sudah menganggap Suwarto seperti anaknya sendiri. Namun, hal berbeda dirasakan oleh Ismiyati yang sangat mencintai Suwarto dan berharap hubungan mereka lebih dari hubungan adik kakak. Suwarto yang tidak mengetahui perasaan Ismiyati, menikahi Mursiwi yang pada saat itu Suwarto pun belum sepenuhnya mengenali tabiat Mursiwi. Meskipun begitu, Ismiyati tetap menyimpan rasa cintanya kepada Suwarto karena ia yakin suatu saat perasaannya akan terbalas.

Konflik batin dalam naskah drama ini berawal ketikan Mursiwi meninggal karena dibunuh oleh seorang laki-laki yang tidak dikenal. Hal tersebut sangat menyudutkan Ismiyati karena ia pernah berkata kepada bapaknya tentang hukuman seseorang yang membunuh karena sakit hati itu berat atau tidak. Marsudi setiap saat menghujani tuduhan kepada Ismiyati yang sebenarnya tidak tahu menau tentang kematian Mursiwi. Alasan apapun yang diberikan oleh Ismiyati sudah tidak didengar oleh Marsudi. Akibat dari kematian Mursiwi, hati Suwarto selalu diselimuti rasa dendam yang begitu besar terhadap pembunuh istrinya. Ismiyati mencoba mencoba menhibur dan mendekati Suwarto, ia merasa kesepatannya mendapatkan Suwarto muncul kembali. Ia menyatakan perasaannya kepada Suwarto dan memintanya untuk melupakan Mursiwi yang sudah tidak ada. Suwarto sama sekali tidak membalas perasaan Ismiyati dan menuduh Ismiyati yang merencanakan pembunuhan Mursiwi. smiyati berkorban dengan segala cara untuk membuka hati Suwarto bahwa ia benar-benar tulus mencintai Suwarto. Tiba-tiba datanglah seorang laki-laki bernama Sulaiman yang mengaku bahwa ia yang telah membunuh Mursiwi, sebab dendamnya pada Mursiwi karena telah dibohongi oleh Mursiwi. Mursiwi meminta begitu banyak uang dan berjanji akan menikah dengan Sulaiman, tidak hanya Sulaiman yangtelah dibohonginya, namun banyak laki-laki yang tela $h$ menjadi korban. Setelah pengakuan Sulaiman, Suwarto sadar dan mau membuka hatinya untuk menerima perasaan Ismiyati.

Analisis tekstual yang ditemukan dalam naskah drama Senja dengan Dua Kelelawar karya Kirdjomulyo.

Berdasarkan hasil analisis di atas, dapat diketahui bahwa analisis tekstual dalam naskah drama Senja 
dengan Dua Kelelawar berdasarkan dua aspek. Aspek yang dimaksud meliputi aspek gramatikal dan aspek leksikal. Analisis aspek gramatikal meliputi empat aspek, yaitu: (1) pengacuan (referensi), (2) penyulihan (substitusi), (3) pelesapan (elipsis), dan (4) perangkaian (konjungsi).

Pada naskah drama Senja dengan Dua Kelelawar peneliti menemukan 730 data pengacuan. Data pengacuan di sini meliputi, pengacuan persona sebanyak 158 data, dan pengacuan komparatif sebanyak 12 data. Pengacuan persona meliputi pengacuan persona tunggal sebanyak 217 data, pengacuan persona pertama jamak 80 data, pengacuan kedua tunggal 146 data, pengacuan kedua jamak 9 data, pengacuan ketiga tunggal 77 data, pengacuan ketiga jamak 31 data.

Pada data pengacuan persona yang banyak ditemukan peneliti adalah pengacuan persona pertama tunggal. Hal ini dapat diketahui dengan seringnya pengarang menggunakan kata ganti orang pertama tunggal baik bentuk bebas $a k u$, saya, bentuk lekat kiri $k u$-, dan bentuk lekat kanan $-k u$. Hal ini juga dikarenakan bahwa data yang dianalisis berupa dialog-dialog sehingga banyak menggunakan kata ganti orang di dalamnya. Hal tersebut sejalan dengan penelitian Saj (2012) yang bejudul

DiscourseAnalysis:

Personal

Pronouns in Oprah Winfrey. Dalam penelitiannya tersebut juga disimpulkan bahwa penggunaan pengacuan persona pertama tunggal yang paling banyak digunakan.

Pengacuan dmostratif dalam hal ini dibagi menjadi dua, yaitu demonstratif tempat dan demonstratif waktu. Dalam naskah drama Senja Dengan Dua Kelelawar penelti menemukan 158 data pengacuan demonstratif dengan 17 data pengacuan demosntratif waktu dan 139 data demonstratif temppat. Pengacuan demonstratif tempat dibagi menjadi empat, yaitu: (1) waktu kini, (2) waktu lampau, (3) waktu yang akan datang, dan (4) waktu netral. Hal yang paling dominan digunakan pengarang dalam naskah drama ini adalah pengacuan demonstratif waktu kini. Dalam naskah drama penggunaannya ditandai dengan menggunakan kata ini, sekarang, dan hari ini.

Adapun untuk pengacuan demostratif tempat ditemukan 139 data. Pengacuan demostratif tempat terbagi menjadi empat, yaitu (1) dekat dengan penutur, (2) agak dekat dengan penutur, (3) jauh dengan penutur, dan (4) menunjuk secara eksplisit. Pada naskah drama Senja Dengan Dua kelelawar yang banyak ditemukan adalah data mengenai demonstratif waktu agak dekat dengan penutur. Hal ini ditandai dengan seringnya pengarang menggunakan kata itu pada setiap dialognya.

Pengacuan komparatif (perbandingan) dalam hal ini bersifat membandingkan dua hal atau lebih yang mempunyai kemiripan atau kesamaan dari segi bentuk / wujud, 
sikap, watak, perilaku, dan sebagainya (Sumarlam,dkk., 2008: 28). Dalam naskah drama Senja dengan Dua Kelelawar menemukan 12 data yang merupakan pengacuan komparatif. Dari 12 data tersebut, 11 data menggunakan kata seperti sebagai penanda pengacuan komparatif, dan hanya 1 data menggunakan kata bagai sebagai penandanya.

Aspek gramatikal yang kedua, yaitu penyulihan (substitusi). Substitusi yang paling dominan dalam naskah drama ini adalah substitusi frasal. Diketahui bahwa substitusi frasal adalah penggantian satuan lingual tertentu berupa kata atau frasa dengan satuan lingual lainnya yang berupa frasa (Sumarlam,dkk., 2003: 29).

Aspek gramatikal yang ketiga, yaitu pelesapan. Dalam hal ini pelesapan yang ditemukan peniliti dalam naskah drama Senja dengan Dua Kelelawar sebanyak 7 data. Pelesapan satuan lingual dapat berupa kata, frasa, klausa, ataupun kalimat. Proses pelesapan dilakukan untuk menghasilkan sebuah kalimat yang efektif sehingga mudah dipahami pembacanya. Selain itu, dengan adanya pelesapan maka tuturan yang dihasilkan menjadi lebih efektif, efisien, wacananya menjadi padu (kohesif), dan memotivasi pembaca untuk lebih kreatif menemukan unsurunsur yang dilesapkan, serta praktis dalam beerkomunikasi.

Aspek gramatikal yang terakhir, yaitu perangkaian (konjungsi). Dalam naskah drama Senja dengan Dua Kelelawar ditemukan 132 data perangkaian (konjungsi). Perangkaian atau konjungsi yang ditemukan dapat menimbulkan beberapa makna. Makna yang dihasilkan dari setiap konjungsi yang digunakan bisa makna sebab akibat, pertentangan, kelebihan, konsesif, tujuan, penambahan, pilihan, harapan, urutan, perlawanan, waktu, syarat, dan cara. Dalan naskah drama ini seluruh aspek gramatikal yang ada terdapat dalam dialog-dialog dalam drama tersebut.

Analisis tekstual berikutnya dilihat dari aspek leksikal. Hal ini sejalan dengan penelitian Andriyani (2013) yang menyatakan bahwa kepaduan wacana novel selain didukung oleh aspek gramatikal juga didukung oleh aspek leksikal. Aspek leksikal adalah bermacam-macam relasi semantik yang terdapat dalam kata (Keraf, 2004: 34). Dalam hal ini, aspek leksikal yang dimaksud meliputi enam aspek, yaitu: (1) repetisi, (2) sinonimi, (3) antonimi, (4) kolokasi, (5) hiponimi, dan (6) ekuivalensi. Dalam naskah drama Senja dengan Dua Kelelawar ditemukan 43 data repetisi, 14 data sinonimi, 7 data antonimi,4 data kolokasi, 1 data hiponimi, dan 6 data ekuivalensi.

Repetisi atau biasanya disebut pengulagan satuan lingual (bunyi, suku kata, kata, atau bagian kalimat) yang dianggap penting untuk memberi tekanan dalam sebuah konteks yang sesuai (Sumarlam,dkk., 2003: 35). 
Dalam naskah drama Senja dengan Dua Kelelawar ditemukan 43 data yang termasuk repetisi. Repetisi atau pengulangan yang terdapat dalam naskah drama Senja dengan Dua Kelelawar hanya ditemukan pada repetisi epizeuksis, repetisi tautotes, dan repetisi anafora.

Sinonimi atau padan kata yang ditemukan dalam naskah drama Senja dengan Dua Kelelawar sebanyak 14 data. Sinonimi adalah bentuk bahasa yang maknanya mirip atau sama dengan bentuk lain; kesamaan itu berlaku bagi kata, kelompok kata, atau kalimat, walaupun umunya yang dianggap sinonim hanyalah kata-kata saja (Kridalaksana dalam Suwandi, 2011: 124). Aspek leksikal sinonimi di sini hanya ditemukan sinonimi morfem (bebas) dan morfem (terikat), sinonimi kata dengan kata, dan sinonimi kata dengan frasa atau sebaliknya, sedangkan untuk sinonimi frasa dengan frasa tidak ditemukan dalam naskah drama Senja dengan Dua Kelelawar. Sinonimi berfungsi menjalin hubungan makna yang sepadan antara satuan lingual tertentu dengan satuan lingual lain dalam wacana (Sumarlam,dkk., 2003: 39).

Aspek leksikal berikutnya, yaitu antonimi atau biasa disebut lawan kata. Dalam naskah drama Senja dengan Dua Kelelawar ditemukan 7 data yang termasuk antonimi. Antonimi yang ditemukan di sini bersifat oposisi mutlak, oposisi kutub, oposisi hubungan, oposisi hierarkial, dan oposisi majemuk. Kolokasi atau sanding kata dalam naskah drama ditemukan 4data. Kata yang berkolokasi di sini merupakan pilihan kata yang digunakan secara berdampingan dan dipakai dalam suatu domain atau jaringan tertentu.

Hiponimi atau hubungan atas bawah merupakan satuan bahasa (kata, frasa, kalimat) yang maknanya dianggap merupakan bagian dari makna satuan lingual yang lain (Sumarlam,dkk., 2003: 45). Hal ini sejalan dengan pendapat Keraf (2004: 38) yang menyatakan hiponimi adalah semacam relasi antar kata yang berwujud atas bawah atau dalam suatu makna terkandung sejumlah komponen yang lain. Dalam naskah drama Senja dengan Dua Kelelawar hanya ditemukan 1 data hiponimi.

Terakhir yang merupakan aspek leksikal, yaitu ekuivalensi. Ekuivalensi berasal dari sejumlah kata hasil proses afiksasi dari morfem yang sama menunjukkan kesepadanan. Dalam naskah drama Senja dengan Dua Kelelawar ditemukan 6 data yang termasuk ekuivalensi. Dapat disimpulkan bahwa dalam analisis secara tekstual baik secara gramatikal dan leksikal kesemuanya tercakup dalam naskah drama yang dikaji.

Dari keseluruhan aspek gramatikal dan leksikal tersebut, bisa disimpulkan bahwa wacana drama Senja dengan Dua Kelelawar bisa disebut wacana yang utuh. Hal ini sejalan dengan penelitian Wiana (2011) yang mengatakan bahwa, suatu wacana dapat disebut wacana yang utuh apabila wacana tersebut memiliki 
pola hubungan gramatikal dan keterpautan semantik antar kalimat yang satu dengan kalimat yang lain.

\section{Analisis kontekstual yang ditemukan dalam naskah drama Senja Dengan Dua Kelelawar karya Kirdjomulyo}

Naskah drama Senja Dengan

Dua Kelelawar selain dikaji secara tekstual juga dikaji secara kontekstual. Analisis berdasarkan konteks memasukkan semua situasi dan hal yang berada di luar teks dan mempengaruhi pemakaian bahasa, seperti partisipan dalam bahasa, situasi dimana teks tersebut diproduksi, fungsi yang dimaksudkan dan sebagainya (Wijana \& Rohmadi, 2008: 74). Hal tersebut dilakukan peneliti agar mengetahui isi naskah drama secara menyeluruh. Perlu diketahui, bahwa analisis kontekstual bertumpu pada teks yang dikaji berdasarkan konteks eksternal yang melingkupinya, baik konteks situasi maupun kultural (Sumarlam, 2006: 98). Menurut Gustianingsih (2006) menyatakan bahwa konteks merupakan wahana terbentuknya teks. Pemahaman sebuah konteks memperhatikan situasi dan budaya dalam wacana dengan menggunakan berbagai prinsip. Ada empat prinsip yang dapat digunakan sebagai acuan, yaitu: (1) prinsip penafsiran personal, (2) prinsip penafsiran lokasional, (3) prinsip penafsiran temporal, dan (4) prinsip analogi.

Prinsip penafsiran personal dapat digunakan sebagai alat bagi para pembaca mengetahui karakter yang ada pada diri tokoh utama. Karakter dalam setiap tokoh tentu saja berbeda tergantung dengan pembawaan dari masing-masing tokoh melalui penggambaran fisik, sifat, dari pengarangnya. Dalam naskah drama Senja Dengan Dua Kelelawar terdapat tiga tokoh sentral di dalamnya, yaitu Suwarto, Ismiyati, dan Mursiwi. Ketiga tokoh tersebut tak lain adalah tokoh utama yang diceritakan dalam drama yang terlibat konflik percintaan diantara ketiganya.

Selain memahami karakter dalam setiap tokoh, tentu saja terjadinya suatu situasi dalam setiap tuturan perlu diketahui agar pembaca memahami situasi tersebut. Pemahaman mengenai situasi dapat diketahui melalui prinsip penafsiran lokasional. Melalui prinsip penafsiran lokasional dapat diketahui keadaan, peristiwa, dan proses berlangsungnya cerita yang ada. Kebanyakan setiap adegan dalam naskah drama ini berlokasi di sebuah tempat yang dekat dengan rel kereta stasiun. Hampir di setiap babaknya dari awal hingga berakhirnya cerita berlangsung di tempat tersebut, yaitu disebuah bangku panjang yang berada di pinggir rel kereta.

Prinsip penafsiran temporal berkaitan dengan pemahaman mengenai waktu. Peristiwa-peristiwa dalam drama Senja Dengan Dua Kelelawar tersusun secara linear (progresif), rapat, dan berurutan. Hal itu disebabkan dalam naskah drama 
tersebut tidak disebutkan secara pasti kapan terjadinya suatu peristiwa itu.

Prinsip analogi digunakan sebagai dasar baik oleh penutur maupun mitra tutur untuk memahami makna dan mengidentifikasi maksud dari (bagian atau keseluruhan) sebuah wacana. Melalui prinsip analogi diketahui bahwa maksud dari setiap dialog yang diperankan setiap tokoh hingga pada akhirnya dapat disimpulkan maksud dari isi drama tersebut. Menarik kesimpulan dari hal tersebut, bahwa drama Senja Dengan Dua Kelelawar menceritakan mengenai cinta dan dendam.

$$
\text { Selain memperlihatkan }
$$

keempat prinsip tersebut, dalam analisis kontekstual juga perlu melihat dari inferensi yang terdapat dalam naskah drama tersebut. Inferensi adalah proses yang harus dilakukan oleh komunikan (pembaca/ pendengar/ mitra tutur) untuk memahami makna yang secara harfiah tidak terdapat dalam wacana yang diungkapkan oleh komunikator (pembicara/ penulis/ penutur) (Sumarlam,dkk., 2003: 51). Inferensi dapat dilihat dari konteks yang terdapat dalam wacana tersebut. Ada empat macam konteks yang terdapat dalam sebuah inferensi, yaitu: (1) konteks fisik, (2) konteks epistemis, (3) konteks linguistik, dan (4) konteks sosial. Keempat konteks tersebut terdapat dalam naskah drama Senja Dengan Dua Kelelawar.

Demikian tadi merupakan pembahasan mengenai analisis tekstual dan kontekstual dalam naskah drama Senja Dengan Dua Kelelawar.
Melalui analisis secara tekstual dan kontekstual dapat diketahui bagaimana isi wacana secara mendalam. Hal ini sejalan dengan penelitian Soimah (2013) yang menyatakan bahwa sebuah wacana dikatakan baik apabila antar kalimat-kalimatnya mempunyai kesinambungan. Pemahaman

mengenai wacana dapat dianalisis melalui analisis wacana tekstual dan analisis wacana kontekstual.

\section{Relevansi Analisis Wacana sebagai Bahan Ajar di Sekolah Menengah Atas}

Berdasarkan analisis data bagian sebelumnya dapat disimpulkan bahwa analisis tekstual dan kontekstual dalam sebuah naskah drama dapat digunakan dan dikembangkan sebagai bahan ajar mata pelajaran Bahasa Indonesia di Sekolah Menengah Atas (SMA). Hal ini terlihat dari kesesuaian analisis wacana baik secara tekstual maupun kontekstual dengan kompetensi dasar yang ada di tingkat pendidikan SMA khususnya pada kelas XI. KD yang terkait dengan penelitian ini ada dua, yaitu: (3.1) menganalisis teks cerita pendek, pantun, cerita ulang, eksplanasi kompleks, dan ulasan / reviu film / drama baik melalui lisan maupun tulisan dan (3.2) mengevaluasi teks cerita pendek, pantun, cerita ulang, eksplanasi kompleks, dan ulasan / reviu film / drama berdasarkan kaidah-kaidah baik melalui lisan maupun tulisan.

Analisis wacana pada umumnya merupakan suatu usaha untuk mengkaji organisasi bahasa di atas 
kalimat atau di atas klausa, dan oleh karena itu, analisis wacana merupakan studi yang lebih luas daripadaunit-unit linguistik, yakni pertukaran percakapan dan kajian teks-teks tertulis (Stubbs dalam Setiawan, 2010: 1). Dalam pngertian tersebut sudah jelas disebutkan bahwa analisis wacana merupakan alat untuk mengkaji secara mendalam sebuah teks-teks tertulis.

Hal ini tentu saja terkait dengan pembelajaran bahasa dimana terdapat materi-materi yang terkait mengenai pemahaman mengenai suatu bacaan. Dengan demikian, analisis wacana relevan untuk digunakanan sebagai bahan ajar bahasa Indonesia yang didasarkan pada isi Peraturan Menteri Pendidikan Nasional RI No. 22 Tahun 2006, diantaranya adalah agar peserta didik memiliki kemampuan berkomunikasi secara efektif dan efisien sesuai dengan etika yang berlaku, baik secara lisan maupun tulis dan menggunakan bahasa Indonesia untuk meningkatkan kemampuan intelektual, serta kematangan emosional dan sosial.

Berkaitan dengan pembahasan di atas dapat diketahui bahwa analisis wacana dapat dijadikan sebagai alat untuk memahami berbagai wacana sastra dan nonsastra secara mendalam oleh peserta didik. Melihat bahwa penelitian ini mengacu pada analisis wacana teks sastra tentu hal ini berkaitan dengan pembelajaran sastra. Pembelajaran sastra di sini bisa mengenai materi puisi, novel, dan drama. Dengan menganalisis wacana sastra secara tekstual dan kontekstual tentu peserta didik mampu memahami wacana sastra dengan baik dan dapat mengapresiasikannya.

Hal ini sejalan dengan pendapat Siti Hariyah selaku guru mata pelajaran Bahasa Indonesia yang menyatakan bahwa penelitian analisis wacana dalam sebuah naskah drama relevan sebagai bahan ajar. Menurutnya penelitian mengenai analisis wacana pada naskah drama ini bisa diterapkan di kelas sehingga nantinya akan lebih mempermudah anak untuk bisa memahami karya sastra tersebut secara umum. Pendapat yang serupa juga dinyatakan oleh Sawitri juga selaku guru mata pelajaran Bahasa Indonesia yang setuju dengan penelitian ini relevan dengan bahan ajar, namun dalam hal ini guru harus mampu memodifikasi sesuai dengan materi ajar yang ada. Pada akhirnya diharapkan melalui analisis wacana tekstual dan kontekstual, pembelajaran sastra dapat berhasil dan ilmu analisis wacana bisa diterapkan dengan baik.

\section{SIMPULAN}

Dari hasil temuan penelitian tentang analisis tekstual dan kontekstual pada naskah drama Senja dengan Dua Kelelawar menunjukkan bahwa nasjah drama tersebut sebagai sebuah wacana menampakkan kepaduan bentuk dan keserasian makna. Kepaduan bentuk dalam naskah drama tersebut didukung oleh aspek gramatikal dan leksikal. Pada aspek gramatikal data pengacuan 
(referensi) sejumlah 644 (83\%). Adapun data penyulihan (substitusi) sejumlah $25(3,5 \%)$, pelesapan (elipsis) sejumlah $8 \quad(1,5 \%)$, dan terakhir perangkaian (konjungsi) sejumlah 95 (12\%). Dari analisis aspek gramatikal data pengacuan merupakan salah satu peranti wacana yang cukup dominan dalam naskah drama Senja dengan Dua Kelelawar.

Adapun analisis aspek leksikal dalam naskah drama Senja dengan Dua Kelelawar ditemukan 51 data $(48,5 \%)$ yang termasuk repetisi (pengulangan). Aspek leksikal sinonimi (padan kata) ada 17 data (16\%), antonimi (lawan kata) ada 7 data (9\%). Kolokasi (sanding kata) dalam naskah drama ditemukan 18 data (17\%), sedangkan hiponimi (hubungan atas bawah) hanya 1 data (1\%), dan ekuivalensi (kesepadanan) sebanyak 14 data (13,5\%). Berdasarkan data aspek leksikal data yang paling banyak ditemukan adalah repetisi (pengulangan). Berdasarkan deskripsi hasil analisis tentang kekohesian baikdari aspek gramatikal maupun leksikal dapat disimpulkan bahwa wacana naskah drama Senja dengan Dua Kelelawar merupakan wacana yang memiliki koherensi.

Secara kontekstual naskah drama Senja dengan Dua Kelelawar dapat dipahami melalui prinsip penafsitran personal, lokasional, temporal, analogi, dan analisis inferensi. Berdasarkan prinsip penafsiran personal diketahui Suwarto adalah sebagai tokoh utama (penutur) dan Ismiyati atau Mursiwi sebagai mitra tutur. Ketiganya adalah pelibat atau saling berperan dalam wacana tersebut, sedangkan lokasi terjadinya suatu situasi atau peristiwa berlangsung di lingkungan stasiun, khususnya bangku yang letaknya dekat dengan rel kereta api yang sebagian cerita dari awal sampai akhir berlokasi di tempat tersebut.

Berdasarkan prinsip penafsiran temporal urutan peristiwa dalam drama ini dimulai dari kisah masa remaja Ismiyati dengan Suwarto yang selalu bersama satu kereta api setiap hari, dari kebiasaan tersebut muncullah perasaan cinta Ismiyati. Namun, Suwarto memilih menikah dengan Mursiwi. Mursiwi yang punya tabiat kurang baik akhirnya dibunuh oleh laki-laki yang memiliki perasaan dendam terhadapnya, laki-laki tersebut adalah Sulaiman mantan pacar Mursiwi yang telah dibohongi oleh Mursiwi. Atas kejadian ini Suwarto marah dan ingin membalaskan dendamnya. Ismiyati yang masih mencintai Suwarto akhirnya berjuang demi perasaannya terhadap Suwarto. Atas apa yang dilakukan Ismiyati selama ini, akhirnya Suwarto mau membuka hati untuk mencintai Ismiyati. Melalui prinsip analogi diketahui bahwa maksud dari setiap dialog yang diperankan setiap tokoh hingga pada akhirnya dapat disimpulkan bahwa drama Senja dengan Dua Kelelawar menceritakan mengenai cinta dan dendam. Dengan demikian, dari tuturan dan mempertimbangkan konteks fisik, konteks epistemis, konteks linguistik 
dn konteks sosial, yang mendasarinya dapat diidentifikasi inferensi yang terdapat di dalamnya.

Berdasarkan analisis ldata pada bagian sebelumnya daapat disimpulkan bahwa analisis wacana tekstual dan kontekstual memiliki potensi untuk digunakan dan dikembangkan sebagai bahan ajar pelajaran Bahasa Indonesia di SMA. Hal ini terlihat dari kesesuaian aspek analisis wacana tekstual dan dengan beberapa kompetensi dasar yang ada di tingkat pendidikan Sekolah Menengah Atas

\section{REFERENSI}

Djajasudarma, T. Fatimmah. (1994).

Wacana Pemahaman dan

Hubungan Antarunsur.

Bandung: PT Eresco.

Gustianingsih. (2006). "Analisis Wacana pada Media Cetak Perspektif Linguistik Fungsional Sistemik (LFS) dan Representasi Semiotik". Jurnal Ilmiah Bahasa dan Sastra, 2 (2), 104-113)

Moleong, J. L. (2000). Metodelogi Penelitian Kualitatif. Bandung: PT Remaja Rosdakarya.

Priyatni, E.T. (2010). Membaca Sastra dengan Ancangan Literasi Kritis. Jakarta: PT Bumi Aksara.

Saj, H. E. (2012). "Discourse Analysis: Personal in Oprah Winfrey". International Journal of Science and Humanity, 2 (6), 529-531

Setiawan, Budi. (2012). Pragmatik: Sebuah Pengantar. Salatiga: Widya Sari Press Salatiga.

Sumarlam, Saddhono, K., Usdiyanto Widyastuti, C.S., Muljani, S., Tarwiyah, S., dkk. (2003). Teori dan Praktik Analisis Wacana.

Surakarta: Pustaka Cakra Surakarta.

Soimah, A. R. (2013). "Analisis Wacana Tekstual dan Kontekstual dalam Novel Prawan Ngisor Kreteg Karya Soetarno". Jurnal Pendidikan, Bahasa, Sastra, dan Budaya Jawa, 03 (04), 19-23.

Waluyo, H. Y. (2003). Drama: Teori dan Pengajarannya. Yogyakarta: PT. Hanindita Graha Widya.

Wijana, I.D.P \& Rohmadi, M. (2008). Semantik: Teori dan Analisis. Surakarta: Yuma Pustaka.

Wijana, I.D.P \& Rohmadi, M. (2011). Analisis Wacana Pragmatik Kajian Teori dan Analisis. Surakarta: Yuma Pustaka. 